Revista de

Contabilidade e

Organizações

www.rco.usp.br
DOI: http://dx.doi.org/10.11606/rco.v7i19.55516
Journal of

Accounting and

Organizations

www.rco.usp.br

\title{
Longitudinal study of the degree of intangibility of the largest banks in Brazil
}

Alessandra C. de Vasconcelos; ; Rosângela F.dos Santos ${ }^{a}$; Márcia M. M. De Luca ${ }^{a}$ Jacqueline V. A. da Cunha ${ }^{\mathrm{b}}$

${ }^{a}$ Faculdade de Economia, Administração, Atuária, Contabilidade e Secretariado Executivo - Universidade Federal do Ceará

${ }^{b}$ Faculdade de Ciências Econômicas, Departamento de Ciências Contábeis - Universidade Federal de Minas Gerais

\section{Article Info}

Article history

Received: 10 May 2012

Accepted: 1 November 2013

Key words

Intangible Assets

International Financial Reporting

Standards

Institutional Theory

\begin{abstract}
In light of Institutional Theory, we observed the behavior of the degree of intangibility of the largest banks listed on the Brazilian stock exchange (BM\&FBovespa) in the period 2007-2010 in order to assess the impact of the introduction of mandatory disclosure of intangible assets in accounting statements associated with the convergence on International Financial Reporting Standards. The study was qualitative and based on an initial sample of the top 50 banks (by equity) on the ranking of "Exame Melhores e Maiores 2010" (list of the top 1,000 firms in Brazil). We found that (i) the explanatory notes were the accounting document most commonly used for the presentation or decomposition of intangibles, (ii) the most representative types of intangible assets were "expenditure on acquisition and software development", "software and systems" and "acquisition of payrolls" with regard to frequency, and "goodwill" and "acquisition of payrolls" with regard to average volume of investment; (iii) the predominant classification of intangible assets was "infrastructure assets", (iv) the degree of intangibility decreased over the study period, and (v) no symmetry was observed between variations in the index of investments in intangible assets and market value.
\end{abstract}

\section{INTRODUCTION}

The role of intangible resources in the composition of assets in organizations is a much debated issue in both the academic and the corporate world, especially since intangible assets are now considered a significant economic resource by firms along with other assets conventionally referred to as "tangible" (PABLOS, 2004; BUKH; LARSEN; MOUTSSEN, 2005).

To Stewart (1998), Edvinsson and Malone (1998) and Santos and Schmidt (2002), the expression "intangible asset" is synonymous with "intellectual capital" or "knowledge asset". As the sum of available knowledge and information, intangible assets aggregate value to the organization. For the purpose of the present study, the expressions "knowledge management", "knowledge asset", "intangible asset", "intangible capital", "intangible resource", "intellectual capital", "goodwill”, "intellectual

Corresponding author: Tel + 5585 3366-7802.

E-mail : alegallon@terra.com.br (A.C.Vasconcelos); rosangela_felix.s@ hotmail.com (R. F. Santos); marciadeluca@ufc.br (M. M. M.Luca); vac@ face.ufmg.br (J. V. A.Cunha).

Universidade Federal do Ceará - Av. da Universidade 2431 Benfica 60020180 - Fortaleza, CE - Brasil property" and "core competences" refer to the same type of asset (BROOKING, 1996; EDVINSSON; MALONE, 1998; SVEIBY, 1997; STEWART, 1998; GUTHRIE; PETTY, 2000; LEV, 2001; REZENDE, 2001; KAUFMANN; SCHNEIDER, 2004; CARVALHO; ENSSLIN, 2006; ANTUNES, 2006).

On December 28, 2007, with the passage of Law 11.638, which significantly changed accounting regulations under Brazilian corporate law (BRAZIL, 1976), Brazilian firms initiated the process of converging on international financial reporting standards (IFRS). In 2009 , the process was further harmonized by the passage of Law 11.941.

The Brazilian Accounting Pronouncements Committee (CPC), a non-profit institution under the Federal Accounting Council providing technical guidelines and information on changes in corporate law and accounting regulations, was instrumental in the transition from Brazilian to international accounting standards (CPC, 2011). Important among the pronouncements of the Committee is CPC 04 on intangible assets, approved by the CVM (the Brazilian equivalent of the US Securities and Exchange Commission) under 553/2008. In effect since January 1st 2009, CPC 04 is analogous to International Accounting Standard (IAS) 38, which 
defines accounting procedures for intangible assets, including guidelines on asset recognition, identification, control, quantification, application and assessment. The pronouncement was later modified by CPC 04 (R1) in 2010, following approval by the CVM (644/2010).

Over the past two decades, investments in intangible assets have grown substantially in various economic sectors, especially in the banking sector. Among other things, banks have introduced IT into their services, invested in customer relations and increased existing intellectual capital by actualizing the potential of their staff. The expertise, creativity, knowledge and problemsolving skills of employees, combined with proper business practices, have significantly raised the trading volume in the financial sector (QUINTEIRO, 2009).

Indeed, according to Calil (2006), the financial sector plays a crucial strategic role in the economy of a nation as well as in foreign relations due to the interdependence of economic systems. Thus, the shifting and highly competitive nature of the financial environment requires national banks to fully assess their unique resources and competitive advantages in relation to international institutions (CALIL, 2006). Laux and Leuz (2009) pointed out that over the past few years the scenario of recurring crises on the financial and capital markets, some of which of global proportions, has led authorities to demand better internal controls and investments on part of the banking industry.

The Brazilian banking sector has undergone profound changes in the last few years. According to Zilber and Pajares (2009), these include (i) the implementation of Plano Real in 1994, a Brazilian economic stabilization program promoted by the federal government which eliminated revenues derived from inflation, amounting to as much as $40 \%$ of total bank revenues, (ii) the introduction of the Program of Incentives to the Restructuring and Strengthening of the National Financial System (PROER) preventing the system from collapsing and greatly intensifying competition in the sector, (iii) increased competition from foreign institutions, the participation of which nearly doubled on the Brazilian market in just 10 years, (iv) the introduction of stricter regulatory policies, (v) the consolidation of the financial sector as the number of active banks fell from 246 in 1994 (year of implementation of Plano Real,) to 156 by the end of 2007 (FEBRABAN, 2011). Silva and Alperstedt (2013) believe that the Brazilian financial system has undergone major transformations, from specialization by segment to concentration of the banking sector, including a substantial number of mergers and acqusitions, in addition to dealing with an array of complex sociopolitical, regulatory, economic, technological and market issues. In the authors' opinion, these transformations have resulted in the modernization of the financial system and in the improvement of the quality of banking services.

In his analysis of the effects of recent changes in the economic scenario, the opening of the market and the stabilization of the banking industry, Assaf Neto
(2012) concludes that the Brazilian banking system is undergoing a process of extensive adjustment to a new market reality, with the emergence of new models of risk assessment and more sophisticated financial operations.

In addition to these changes-and highly relevant to the objective of the present study-important modifications have been made to the Brazilian accounting legislation, especially with regard to the mandatory disclosure of intangible assets in accounting statements since the beginning of 2008. According to the Brazilian Federation of Banks (FEBRABAN, 2011), banks have invested more in IT than any other Brazilian sector. This is not surprising: since information in this sector doubles as input and product, most banking products and services are highly IT-intensive (MEIRELLES, 2010).

In view of the increase in IT use, networking, e-business, information flow and patent registration and changes in bank management strategies over the past 20 years (QUINTEIRO, 2009), the issue of intangible assets has gained unprecedented importance in the analysis, management and evaluation of financial institutions. This may explain the presence of three $(30 \%)$ financial institutions among the ten most intangible asset-intensive organizations in Brazil, according to a survey sponsored by The Brander (2009) in partnership with Intangible Asset Management (IAM) Consulting.

Persuaded by the results of academic research showing the influence of the evolution in IT on the economic scenario, organizations are increasingly aware of the need to recognize and quantify their intangible resources (LUCENA et al., 2009). In this context the present study aims at answering the following question: What is the behavior of the degree of intangibility of the largest banks listed on the Brazilian stock exchange BM\&FBovespa in the period 2007-2010? Thus, the general objective is to analyze, in light of Institutional Theory, the behavior of the degree of intangibility of the largest banks listed on BM\&FBovespa in the period 2007-2010 with the purpose of evaluating the impacts of the mandatory introduction of new accounting practices regarding intangible assets in the accounting statements of these firms.

In order to attain this objective, the following specific objectives were formulated: i) to identify the composition of intangible assets according to the classification proposed by Brooking (1996), expressed in terms of frequency and volume of investment, ii) to evaluate the distribution of categories of intangible assets in relation to total assets and non-current assets in the period 2007 2010 , iii) to analyze variations in the degree of intangibility and in the Index of Investment in Intangible Assets (IIIA) according to company size and stock market segment, iv) to compare the degree of intangibility and investments in intangible assets before and after the introduction of mandatory disclosure of intangible assets in accounting statements, and v) to verify the existence of symmetry between IIIA and market value in the period 2009-2010.

The study is intended to subsidize the discussion on intangibility in the financial sector, considering 
the important role played by banks in financing the economic development of the country and integrating the population with the credit/financial services market. Our approach to evaluating the impact on the country's largest banks of the introduction of international financial reporting standards-which involved aspects such as law enforcement and served the interest of regulatory decisions and of the market as a whole-is relevant due to the segregation of intangible assets into categories (BROOKING, 1996), making it possible to determine the distribution of assets by category and the relation of each category to company market value.

In addition, the recent changes in the Brazilian economic scenario, such as the reductions in spread and interest rates and the financial inclusion of the Brazilian population, require researchers on management and finances in financial institutions to focus on longer periods of time, as in the present study and as in the analysis by Almeida et al. (2012) on the influence of the world financial crisis on the structure of the top Brazilian banks which was divided into three distinctive periods: before the crisis (2006-2007), during the crisis (20082009) and after the crisis (2010-2011).

\section{THEORETICAL FRAMEWORK}

\subsection{Intangible Assets}

Kohler's definition of intangible assets (IA) is still regarded by many scholars as one of the most adequate: capital asset having no physical existence, its value being limited by the rights and anticipative benefits that possession confers upon the owner (KOHLER, 1957). In turn, CPC 04 (2008), item 8, defines intangibles as identifiable non-monetary assets without physical substance, and recommends their identification by the organization.

Lev (2001) considers intangible assets to be rights and claims to expected benefits without physical or financial substance originating from discoveries, organizational practices and human resources. With emphasis on the ability of intangible assets to create value, Kayo (2002) sees in them a structured set of knowledge, practices and attitudes interacting with the organization's tangible assets to compound company value.

Intangibles constitute an important element in the study of accounting theory, especially after the realization of their value to organizations (IUDÍCIBUS, 2004) and express a potential for future economic benefits. Hendriksen and Van Breda (2007, p. 387) stress that to be defined as assets, intangibles must satisfy the criteria for recognizing any type of asset, that is, "they should be measurable, relevant and reliable".

According to the definition given in CPC 04, intangible assets must be (i) separable from the organization, sellable, transferable, licensable, rentable, exchangeable and includable in/excludable from contracts, or (ii) the result of contractual and other legal rights (CPC, 2008).

The current interest in intangible assets is explained by changes in organizational structures associated with increased competition and IT developments, making such assets major indicators of company value (LEV, 2001). To Perez and Famá (2006a), intangibles such as brands, patents, intellectual capital and authors' rights are unique assets, usually as a result of innovation and knowledge. Likewise and Crisóstomo (2009) believes corporate wealth is created by means of innovation.

Despite the importance attributed to intangible assets, there is so far no consensus in the literature regarding their classification. Table 1 shows a number of possible classifications.

Table 1. Classification of intangible assets.

\begin{tabular}{|c|c|c|}
\hline Author (year) & Classification & Composition \\
\hline \multirow{5}{*}{ Brooking (1996) } & Market assets & $\begin{array}{l}\text { Company potential derived from market-related intangible assets (e.g. } \\
\text { brands, customer portfolios, customer loyalty, recurrent business, ongoing } \\
\text { business, distribution channels) }\end{array}$ \\
\hline & Human-centered assets & $\begin{array}{l}\text { Company potential derived from the expertise, creativity, knowledge } \\
\text { and problem-solving skills of individuals, considered collectively and } \\
\text { dynamically }\end{array}$ \\
\hline & $\begin{array}{l}\text { Intellectual property } \\
\text { assets }\end{array}$ & $\begin{array}{l}\text { Assets that require legal protection in order to benefit organizations (e.g. } \\
\text { know-how, industrial secrets, copyrights, patents, design) }\end{array}$ \\
\hline & Infrastructure assets & $\begin{array}{l}\text { Technologies, methodologies and processes (e.g. organizational culture, } \\
\text { information systems, management methods, risk acceptance, customer } \\
\text { databases) }\end{array}$ \\
\hline & $\begin{array}{l}\text { Intellectual capital/ } \\
\text { property }\end{array}$ & Asset resulting from a creative process attributable to specific individuals \\
\hline
\end{tabular}




\begin{tabular}{|c|c|c|}
\hline \multirow{3}{*}{ Sveiby (1997) } & External structures & $\begin{array}{l}\text { Brands, registered trade marks, relationship with customers and suppliers, } \\
\text { corporate image }\end{array}$ \\
\hline & Internal structures & $\begin{array}{l}\text { Organizational structure, management structure, legal structure, systems, } \\
\text { R\&D, software, etc. }\end{array}$ \\
\hline & Individual competences & $\begin{array}{l}\text { Ability of staff to act in different situations to create tangible and } \\
\text { intangible assets }\end{array}$ \\
\hline \multirow[b]{2}{*}{ Edvinsson and Malone (1998) } & Human capital & $\begin{array}{l}\text { Combination of knowledge, skills, staff's capacity for innovation in } \\
\text { solving tasks, values, corporate culture and philosophy }\end{array}$ \\
\hline & Structural capital & $\begin{array}{l}\text { Organizational capital: hardware, software, data bases, organizational } \\
\text { structure, patents, brands or whatever supports productivity. May be } \\
\text { divided in innovation capital and process capital } \\
\text { Customer capital: customers and relations developed with them }\end{array}$ \\
\hline \multirow{3}{*}{ Stewart (1998) } & Human resources & Talents and skills of staff \\
\hline & Structural capital & $\begin{array}{l}\text { Information systems, patents, processes, databases and other internal } \\
\text { intangible resources }\end{array}$ \\
\hline & Relational capital & Relationship with customers and suppliers \\
\hline \multirow{3}{*}{$\begin{array}{l}\text { Roos, Edvinsson and Roos } \\
\text { (1998) }\end{array}$} & Human capital & Divided into competences, attitude and intellectual agility \\
\hline & Structural capital & Divided into relationships, organization, renovation of development \\
\hline & Relational capital & Suppliers, customers, services providers and other important stakeholders \\
\hline \multirow{3}{*}{ Lev (2001) } & Innovation & Investments in $R \& D$, pure or applied \\
\hline & $\begin{array}{l}\text { Unique organizational } \\
\text { designs }\end{array}$ & $\begin{array}{l}\text { Internal intangible resources exclusive to the organization, i.e. unique } \\
\text { structures and systems }\end{array}$ \\
\hline & Human resources & Talents and skills of staff \\
\hline
\end{tabular}

Source: the authors, based on a review of the literature.

It may be seen from Table 4 that some intangible assets, such as human resources, are more difficult than others to identify, quantify and control.

For the purpose of this study, we adopted the classification proposed by Brooking (1996) which segregates intangible assets into market assets, human-centered assets, intellectual property assets and infrastructure assets. Over the past decade, this classification has been employed by a number of researchers, including Allee (2000), Marr, Schiuma and Neely (2004), Bollen, Vergauwen and Schnieders (2005) and Kot (2009), and in a wide range of empirical settings (ANTUNES; LEITE, 2008; SANTOS; SILVA; GALLON, 2011). However, as pointed out by Marques (2009, p. 195), "no single method can satisfy all purposes and needs: researchers should select the method most appropriate for the purpose, the context and the audience (internal or external) of the study".

As explained by Antunes and Leite (2008), not all intangible assets are included in accounting statements due to the difficulty in measuring their cost and synergistic effects with other assets. This is an important observation in view of our purpose of identifying the intangible assets disclosed in the accounting statements of the largest banks in Brazil, in compliance with the recent changes in corporate law, and evaluating fluctuations in the degree of intangibility.

The proportion of intangibles (such as brand names, patents and formulas) in relation to firm value has grown dramatically, especially since the 1980s (KAYO; FAMÁ, 2004). These authors used the ratio between market value and book value as a proxy for the level of intangibility, as we shall see in the following section.

\subsection{Degree of Intangibility: a Review of the Literature}

The concern of scholars with growth in firm value (market, stock exchange) reflects the common understanding that intangible factors are playing an increasing role in the total value of organizations. Indeed, Antunes and Martins (2007) believe the discussion on intangible assets in the academic and corporate context is 
highly relevant to the creation of wealth in organizations. The overall growth in the degree of intangibility may be attributed to increasing competition on the globalized market and the impact of new technologies on organizational structure (LEV, 2001).

Obtained by dividing the organization's market value by its book value (equity), the degree of intangibility (DI) indicates the proportion of intangible assets in relation to total assets (PEREZ; FAMÁ, 2006a, 2006b; COLAUTO et al., 2009). Thus, the calculation of DI is based on the assumption that "what is left of market value when fixed assets are subtracted must correspond to intangible assets" (STEWART, 1998, p. 201).

In other words, DI expresses the number of times the market value (total value of shares) is greater than equity as disclosed in accounting statements (ENSSLIN et al., 2009). The greater the difference between the values, the greater the degree of intangibility. To Kayo and Famá (2004), the ratio between the total price of shares and the value provided in accounting statements is a helpful indicator in the analysis of discrepancies in company value.

The relation between market value and book value has always been of interest to accounting. Santos and Schmidt (2009) reported that worldwide the average market value is twice the book value, but in the US the difference may be from 2 to 9 times. This is explained by the importance acquired over the years by intangible assets in detriment of tangible assets and by the difficulty in identifying, quantifying and recognizing such assets (ANTUNES; LEITE, 2008).

Perez and Famá (2006a) analyzed the impact of unrecorded intangible assets on business performance to determine whether such assets contributed significantly to the creation of value for shareholders. They inferred that, during the study period, tangible assets were responsible for regular earnings only, while true creation of value was ascribed to intangible assets.

In the present study, DI and IIIA were calculated based on accounting statements issued for the financial exercises ending on December 31st 2007, 2008, 2009 and 2010, respectively, in order to evaluate the impact of the introduction of stricter accounting regulations in 2007 (Law 11.638).

The introduction of mandatory disclosure of intangible assets, in association with the convergence on IFRS, is in this study considered an institutional issue, despite the opinion of Lima et al. (2010) that changes in accounting regulations cannot be interpreted without taking into account other elements of institutional infrastructure, and that international standards allow for a substantial amount of discretion on part of the organization since the process of quantification involves judgments based on private information.

As explained by Crubellate (2007), in this perspective the institutional environment is seen as a determinant of organizational behavior, or at least as a variable independent of it. In turn, Dimaggio and Powell
(1983) believe organizations tend to conform to the environment, thereby promoting structural isomorphism, and that the existence of institutional isomorphism shows that organizations compete not only for resources and customers, but also for political influence and institutional legitimacy (DIMAGGIO; POWEL, 1983).

Finally, it should be pointed out that the question of convergence on international accounting standards has been analyzed in light of Institutional Theory, as in the present study, by several researchers over the past decade, including Ball, Kothari and Robin (2000), Irvine (2000), Hopwood (2000), Carpenter and Feroz (2001), Potter (2005) and Nobes (2006).

\section{METHODOLOGY}

This was an explorative study, based on a review of documents and the literature. Our investigation was qualitative in view of the absence of statistical analysis. In this type of approach, statistical correlations are replaced by descriptions and causal connections evidenced by the interpretation of qualitative data (MARTINS; BICUDO, 1989). The qualitative design provides a detailed understanding of situational characteristics and meanings (RICHARDSON, 1999) and therefore was found to be an adequate approach to answer our research question regarding the behavior of the degree of intangibility of the largest banks on the Brazilian stock exchange in the period 2007-2010.

The choice of the financial sector to compose the study sample was based on the results of a survey of the ten most intangible asset-intensive firms in Brazil in 2008 (THE BRANDER, 2009), in which the financial sector was shown to be the most representative (30\%). Subsequently, we selected the 50 largest banks from the ranking of the top 1,000 firms in Brazil published by "Exame Melhores e Maiores 2010", based on equity disclosed in accounting statements for 2009.

Banks not listed on the BM\&FBovespa stock exchange were excluded from the sample, followed by the exclusion of banks disclosing zero value (BRL 0.00) intangible assets in their accounting statements for the entire study period (2007-2010).

Thus, of the initial sample of 50 banks, 27 met the first criterion of exclusion (no listing on BM\&FBovespa) and 4 met the second criterion (zero value intangible assets disclosed). In addition, the bank Votorantim Finanças S.A. was excluded due to lacking information on market value for the study period, leaving a final sample of 18 banks (Table 2). 
Table 2. Final study sample.

\begin{tabular}{|c|c|c|}
\hline Ranking (Exame, 2009) & Bank & Code assigned \\
\hline $1 \mathrm{st}$ & Itaú Unibanco Holding S.A. & B1 \\
\hline 2nd & Banco Santander (Brasil) S.A. & $\mathrm{B} 2$ \\
\hline $3 \mathrm{rd}$ & Banco Bradesco S.A. & B3 \\
\hline 4 th & Banco do Brasil S.A. & B4 \\
\hline 9th & Banco do Estado do Rio Grande do Sul - Banrisul & B5 \\
\hline 15 th & Banco Amazônia S.A. & B6 \\
\hline 16 th & Banco Industrial e Comercial S.A. - Bicbanco & B7 \\
\hline 18 th & Banco Daycoval S.A. & B8 \\
\hline 19th & Banco Alfa de Investimento S.A. & B9 \\
\hline 20th & Banco Panamericano S.A. & $\mathrm{B} 10$ \\
\hline $23 \mathrm{rd}$ & Banco ABC Brasil S.A. & B11 \\
\hline 25 th & Banco Cruzeiro do Sul S.A. & $\mathrm{B} 12$ \\
\hline 29th & Banco Pine S.A. & B13 \\
\hline 30 th & Paraná Banco S.A. & B14 \\
\hline $32 \mathrm{nd}$ & Banco Sofisa S.A. & B15 \\
\hline 34 th & Banco do Estado do Espírito Santo S.A. - Banestes & B16 \\
\hline 38 th & BRB Banco de Brasília S.A. & B17 \\
\hline 39 th & Banco Mercantil do Brasil S.A. & B18 \\
\hline
\end{tabular}

Source: Data retrieved from "Exame Melhores e Maiores 2010".

Table 2 shows the final sample of banks analyzed in the study. The left column indicates the position of each bank in the ranking of the largest banks in Brazil (by equity) published in "Exame Melhores e Maiores 2010". In the right column, we have assigned a code to each institution to facilitate the presentation and discussion of results.

We consider our sample significant and representative of the population as it comprises many of the country's largest banks, and probably also the best organized in terms of documentation and the recording of accounting numbers. Nevertheless, despite strict adherence to proper scientific methodology, the study was limited by the reduced sample size, which did not allow for a quantitative statistical analysis, reinforcing the qualitative element of the study. Rather, our study may be viewed as an effort to draw a profile of this important group of financial institutions and as the first step in a larger investigation of intangible assets in the Brazilian banking sector.

was collected to identify the categories and determine the representativeness of the intangible assets disclosed in the accounting statements of the sampled banks, using the classification system proposed by Brooking (1996) (Table 1).

The representativeness of each category of intangible assets was determined by vertical analysis, dividing the amount of intangible assets by the amount of non-current assets, and the amount of intangible assets by the amount of total assets of each bank for each year in the study period (2007, 2008, 2009 and 2010).

IIIA and DI were obtained using the equations presented in Table 3. The equations have been used in several previous studies on intangibility (KAYO; FAMÁ, 2004; PEREZ; FAMÁ, 2006a, 2006b; COLAUTO et al., 2009; RITTA; ENSSLIN, 2010).

Once the final sample had been defined, information

Table 3. Indicators and equations used in the study.

\begin{tabular}{|c|c|c|}
\hline INDICATOR & EQUATION & INDICATES... \\
\hline $\begin{array}{l}\text { Index of Investment in Intangible Assets } \\
\text { (ША) }\end{array}$ & $\begin{array}{l}\text { Intangible assets / total } \\
\text { assets (equity) }\end{array}$ & $\begin{array}{l}\text { The proportion between investments in intangible assets } \\
\text { and equity }\end{array}$ \\
\hline Degree of Intangibility (DI) & market value / book value & $\begin{array}{c}\text { The number of times market value is greater than book } \\
\text { value, represented by equity }\end{array}$ \\
\hline
\end{tabular}

Source: Adapted from Perez and Famá (2006a, 2006b), Patrocínio, Kayo and Kimura (2007) and Ritta and Ensslin (2010). 
The figures for intangible assets and equity (book value) were retrieved from accounting statements (balance sheet and explanatory notes to the accounting statements) available on the website of BM\&FBovespa. The market value of the banks in the sample was retrieved from the database Economática ${ }^{\circledR}$.

\section{DESCRIPTION AND ANALYSIS OF RESULTS}

4.1 Composition and Categorization of Intangible Assets in Terms of Frequency and Investments Disclosed in Accounting Statements

Table 4 shows the number and percentage of banks disclosing investments in intangible assets (i.e. intangible assets of which the value is other than zero) segregated by category in accounting statements issued during the period covered by the study.

Table 4. Composition of intangible assets in accounting documents issued by the banks in the sample, organized according to type, period, number and percentage.

\begin{tabular}{|c|c|c|c|c|c|c|c|c|}
\hline \multirow{3}{*}{ Accounting statements } & \multicolumn{8}{|c|}{ Number and percentage of banks per year } \\
\hline & \multicolumn{2}{|c|}{2007} & \multicolumn{2}{|c|}{2008} & \multicolumn{2}{|c|}{2009} & \multicolumn{2}{|c|}{2010} \\
\hline & $\mathbf{N}$ & $\%$ & $\mathbf{n}$ & $\%$ & $\mathbf{n}$ & $\%$ & $\mathbf{n}$ & $\%$ \\
\hline Balance sheet & 0 & $0 \%$ & 0 & $0 \%$ & 0 & $0 \%$ & 0 & $0 \%$ \\
\hline Explanatory notes & 8 & $67 \%$ & 11 & $69 \%$ & 13 & $72 \%$ & 13 & $76 \%$ \\
\hline Balance sheet and explanatory notes & 1 & $8 \%$ & 1 & $6 \%$ & 1 & $6 \%$ & 1 & $6 \%$ \\
\hline No categorization / decomposition & 3 & $25 \%$ & 4 & $25 \%$ & 4 & $22 \%$ & 3 & $18 \%$ \\
\hline TOTAL & 12 & $100 \%$ & 16 & $100 \%$ & 18 & $100 \%$ & 17 & $100 \%$ \\
\hline
\end{tabular}

Source: Data collected for the study (2011).

As seen in Table 4, explanatory notes were the type of document most frequently used to present or decompose intangible assets, probably because of recommendations of CPC 04 to the effect of segregating intangible assets by category in explanatory notes only. With regard to the disclosure of intangible assets in explanatory notes, it should be noted that IAS 38 (2008) requires the disclosure of at least the following items:

(i) the useful life or amortization rate used,

(ii) the amortization method used,

(iii) gross book value and accumulated amortization (aggregated with accumulated impairment losses) at the beginning and end of the period,

(iv) the items of each line of the income statement in which the amortization of intangibles is included, and

(v) reconciliation of the amounts registered at the beginning and end of the period.

The percentage of banks disclosing the composition of intangible assets in explanatory notes increased from $75 \%$ in 2007 to $82 \%$ in 2010 .

Changes were particularly visible in the aftermath of the passage of Law number 11.638/07 and the publication in 2008 of CPC 04, suggesting the introduction of new regulations produced a positive impact on disclosure practices and on the quality of accounting information. Iudícibus et al. (2010) and Santos et al. (2011) reached similar conclusions.

The observed increase in the number of banks disclosing intangible assets and in the practice of segregating assets by category in accounting reports is supported by the findings of Antunes (2006), Reina, Vicente and Ensslin (2008) and Arruda, Cabral and Araújo (2010) who-in addition to quantitative growthreported qualitative improvements in the reporting of intangible assets of Brazilian firms.

Furthermore, to remain competitive, service providers (such as banks offering financial intermediation) have to develop their IT capabilities. Adequate technical knowledge and well-designed information systems have become indispensable for individuals and organizations intent on rendering quality services, indicating an increase in intangible assets in these organizations (MARQUES, 2009).

Table 5 presents types of intangible assets according to frequency (number of times the information was disclosed in reports) and average investment (in BRL and $\%$ ) obtained by dividing the sum of the values for each type by the number of financial exercises $(n=4)$ within the study period. 
Table 5. Frequency and average investment in types of intangible assets as disclosed in the accounting statements of the banks in the sample.

\begin{tabular}{|c|c|c|c|c|c|c|c|}
\hline \multirow{2}{*}{ Types of intangible assets } & \multicolumn{4}{|c|}{ Period } & \multirow{2}{*}{$\begin{array}{l}\text { Mean } \\
\text { frequency }\end{array}$} & \multicolumn{2}{|c|}{ Mean investment in the period } \\
\hline & 2007 & 2008 & 2009 & 2010 & & BRL & $\%$ \\
\hline Goodwill on incorporation & 0 & 1 & 0 & 0 & 0.25 & 573,000 & $0.00 \%$ \\
\hline $\begin{array}{l}\text { Goodwill on acquisition of } \\
\text { subsidiaries }\end{array}$ & 0 & 2 & 2 & 1 & 1,25 & 606,750 & $0.00 \%$ \\
\hline Acquisition of banking rights & 1 & 1 & 1 & 1 & 1.00 & $1,590,195,000$ & $7.85 \%$ \\
\hline $\begin{array}{l}\text { Promotion and provision of financial } \\
\text { services and products }\end{array}$ & 1 & 1 & 1 & 1 & 1.00 & $993,897,750$ & $4.91 \%$ \\
\hline Improvements to third-party property & 0 & 0 & 0 & 1 & 0.25 & 1,250 & $0.00 \%$ \\
\hline IT developments & 0 & 0 & 0 & 1 & 0.25 & $601,373,250$ & $2.97 \%$ \\
\hline $\begin{array}{l}\text { Rights to management of investment } \\
\text { funds }\end{array}$ & 1 & 1 & 1 & 1 & 1.00 & $219,175,000$ & $1.08 \%$ \\
\hline Acquisition of payrolls & 3 & 3 & 4 & 3 & 3.25 & $5,821,139,000$ & $28.74 \%$ \\
\hline Expenditure on software acquisition & 1 & 1 & 2 & 2 & 1.50 & $384,137,000$ & $1.90 \%$ \\
\hline $\begin{array}{c}\text { Expenditure on acquisition and } \\
\text { software development }\end{array}$ & 6 & 6 & 6 & 3 & 5.25 & $622,087,500$ & $3.07 \%$ \\
\hline $\begin{array}{c}\text { Expenditure on setup of operational } \\
\text { system }\end{array}$ & 1 & 1 & 0 & 0 & 0.50 & 395,500 & $0.00 \%$ \\
\hline Goodwill & 0 & 0 & 1 & 4 & 1.25 & $7,858,561,500$ & $38.79 \%$ \\
\hline Licenses & 0 & 1 & 1 & 1 & 0.75 & $21,647,000$ & $0.11 \%$ \\
\hline Brands & 0 & 0 & 0 & 1 & 0.25 & 7,000 & $0.00 \%$ \\
\hline Patents & 0 & 0 & 0 & 1 & 0.25 & 7,000 & $0.00 \%$ \\
\hline Customer portfolios & 0 & 1 & 1 & 3 & 1.25 & $165,568,750$ & $0.82 \%$ \\
\hline Contracts & 0 & 0 & 0 & 1 & 0.25 & $81,767,500$ & $0.40 \%$ \\
\hline $\begin{array}{c}\text { Software, developed and under } \\
\text { development }\end{array}$ & 0 & 2 & 2 & 3 & 1.75 & $1,470,909,000$ & $7.26 \%$ \\
\hline Software and systems & 2 & 4 & 6 & 7 & 4.75 & $422,074,250$ & $2.08 \%$ \\
\hline Other intangible assets & 3 & 0 & 6 & 11 & 5.01 & $3,376,000$ & $0.02 \%$ \\
\hline TOTAL & 19 & 25 & 34 & 46 & 31.01 & $20,257,499,000$ & $100.00 \%$ \\
\hline
\end{tabular}

Source: Data collected for the study (2011).

Twenty types of assets were identified among the intangible assets disclosed by the banks in the sample (Table 5). Certain types of assets were increasingly recognized, or more fully disclosed, towards the end of the study period, especially "improvements to thirdparty property", "goodwill", "brands", "customer portfolio-related assets" and "contract-related assets" (classified as market assets), "IT developments", "cost of software acquisition", "software-developed and under development" and "software and systems" (classified as infrastructure assets), and "patents" (classified as intellectual property assets).

The highest average frequency was observed for the types "acquisition of payrolls" (3.25), "cost of software acquisition and development" (5.25), "software and systems" (4.75) and "other intangible assets" (5.01). The lowest average frequency was observed for the types "goodwill on incorporation", "improvements to third- party property", "IT developments", "brands", "patents" and "contract-related assets" ( 0.25 in all cases).

IAS 38 (2008) defines goodwill as an additional value paid in a business combination with regard to the acquirer's participation in the fair value of the acquiree's identifiable assets and liabilities. The norm also specifies that the acquirer must acknowledge identifiable net assets in the business combination, including assets not listed in the acquiree's financial statements. The full amount paid to acquire a firm in a business combination should be disclosed in the individual statements of the acquirer, with no segregation of goodwill, if any. IFRS 3 (R) (2010), which regulates business combinations, determines that intangible assets should be quantified according to their fair value on the date of acquisition.

In terms of average investment, the most representative types were "goodwill" (classified as a market asset) 
$(38.79 \%)$ and "acquisition of payrolls" (classified as a human-centered asset) $(28.74 \%)$. It should be added that, according to item 49 of IAS 38 (2008), goodwill generated internally in the firm, that is, goodwill involving spending with the purpose of obtaining future advantages, does not necessarily result in the creation of a new intangible asset if the costs involved are not adequately quantified.

In a study on the identification, measurement, valuation and recognition of intangible assets in accounting statements issued in 2006 and 2007 by firms listed in the Portuguese Stock Index (PSI-20, a major Portuguese market reference index), Marques (2009) observed the highest average frequency of disclosure of the types "goodwill", "spending on R\&D", "software and industrial property and other rights", "intangible assets in progress", "acquisition of subsidiaries or jointly controlled firms", "licenses for exploitation and concessions", "incorporeal assets in progress" and "brands". As for investments in R\&D, IAS 38 (2008) specifies that spending on research should be acknowledged as an expenditure when incurred, while spending on development should be considered an intangible asset, as long as it meets certain requirements, especially the ability to be used or sold in the future.

Table 6 shows the distribution of investments in intangible assets of the banks in the sample, organized according to period, amount (BRL) and proportion in relation to total investments in intangible assets (BROOKING, 1996). Whenever brands and patents were presented in accounting statements as a single type, we segregated the item into "brands" (a market asset) and "patents" (an intellectual property asset) in accordance with the classification adopted (BROOKING, 1996).

Table 6. Distribution of investments in intangible assets (IA) of the banks in the sample, organized according to period, value and percentage of total investment in IA (Brooking, 1996).

\begin{tabular}{|c|c|c|c|c|c|c|c|}
\hline \multirow[b]{2}{*}{ Bank } & \multirow[b]{2}{*}{ Year } & \multirow{2}{*}{$\begin{array}{l}\text { Total value of } I A \\
\text { disclosed in accounting } \\
\text { reports (BRL) }\end{array}$} & \multicolumn{5}{|c|}{$\begin{array}{l}\text { Participation of IA categories in total value of IA } \\
\text { disclosed in accounting statements }\end{array}$} \\
\hline & & & $\begin{array}{c}\text { Market } \\
\text { assets }\end{array}$ & $\begin{array}{c}\text { Human- } \\
\text { centered } \\
\text { assets }\end{array}$ & $\begin{array}{c}\text { Intellectual } \\
\text { property } \\
\text { assets }\end{array}$ & $\begin{array}{c}\text { Infrastructure } \\
\text { assets }\end{array}$ & $\begin{array}{l}\text { Other } \\
\text { IA }\end{array}$ \\
\hline \multirow{4}{*}{ Itaú Unibanco } & 2007 & $2,820,024,000$ & $10 \%$ & $75 \%$ & $8 \%$ & $6 \%$ & $1 \%$ \\
\hline & 2008 & $3,843,226,000$ & $23 \%$ & $60 \%$ & $8 \%$ & $9 \%$ & $0 \%$ \\
\hline & 2009 & $3,748,220,000$ & $37 \%$ & $45 \%$ & $5 \%$ & $13 \%$ & $0 \%$ \\
\hline & 2010 & $3,244,000,000$ & $44 \%$ & $35 \%$ & $5 \%$ & $16 \%$ & $0 \%$ \\
\hline \multirow{4}{*}{ Santander } & 2007 & $1,791,342,000$ & $0 \%$ & $79 \%$ & $0 \%$ & $21 \%$ & $0 \%$ \\
\hline & 2008 & $28,449,908,000$ & $91 \%$ & $6 \%$ & $0 \%$ & $3 \%$ & $0 \%$ \\
\hline & 2009 & $26,155,836,000$ & $90 \%$ & $4 \%$ & $0 \%$ & $5 \%$ & $1 \%$ \\
\hline & 2010 & $35,583,262,000$ & $92 \%$ & $0 \%$ & $0 \%$ & $7 \%$ & $1 \%$ \\
\hline \multirow{4}{*}{ Bradesco } & 2007 & $2,215,493,000$ & $0 \%$ & $0 \%$ & $57 \%$ & $41 \%$ & $2 \%$ \\
\hline & 2008 & $3,312,833,000$ & $14 \%$ & $0 \%$ & $48 \%$ & $36 \%$ & $2 \%$ \\
\hline & 2009 & $5,516,024,000$ & $40 \%$ & $0 \%$ & $29 \%$ & $30 \%$ & $1 \%$ \\
\hline & 2010 & $5,412,088,000$ & $30 \%$ & $0 \%$ & $35 \%$ & $34 \%$ & $1 \%$ \\
\hline \multirow{2}{*}{ Banco do Brasil } & 2009 & $5,676,879,000$ & $0 \%$ & $93 \%$ & $0 \%$ & $7 \%$ & $0 \%$ \\
\hline & 2010 & $13,842,278,000$ & $47 \%$ & $41 \%$ & $0 \%$ & $5 \%$ & $7 \%$ \\
\hline \multirow{4}{*}{ Banrisul } & 2007 & $199,464,000$ & $0 \%$ & $99 \%$ & $0 \%$ & $1 \%$ & $0 \%$ \\
\hline & 2008 & $204,471,000$ & $0 \%$ & $97 \%$ & $0 \%$ & $3 \%$ & $0 \%$ \\
\hline & 2009 & $180,129,000$ & $0 \%$ & $96 \%$ & $0 \%$ & $4 \%$ & $0 \%$ \\
\hline & 2010 & $172,206,000$ & $0 \%$ & $94 \%$ & $0 \%$ & $5 \%$ & $1 \%$ \\
\hline \multirow{3}{*}{$\begin{array}{l}\text { Banco da } \\
\text { Amazônia }\end{array}$} & 2008 & $114,454,000$ & $0 \%$ & $0 \%$ & $0 \%$ & $100 \%$ & $0 \%$ \\
\hline & 2009 & $115,150,000$ & $0 \%$ & $0 \%$ & $0 \%$ & $100 \%$ & $0 \%$ \\
\hline & 2010 & $114,864,000$ & $0 \%$ & $0 \%$ & $0 \%$ & $100 \%$ & $0 \%$ \\
\hline \multirow{3}{*}{ Bicbanco } & 2008 & 978,000 & $0 \%$ & $0 \%$ & $0 \%$ & $100 \%$ & $0 \%$ \\
\hline & 2009 & $2,298,000$ & $0 \%$ & $0 \%$ & $0 \%$ & $100 \%$ & $0 \%$ \\
\hline & 2010 & $109,512,000$ & $87 \%$ & $0 \%$ & $0 \%$ & $8 \%$ & $5 \%$ \\
\hline Banco Alfa & 2010 & 192,000 & $0 \%$ & $0 \%$ & $0 \%$ & $83 \%$ & $17 \%$ \\
\hline \multirow{4}{*}{ Panamericano } & 2007 & $3,949,000$ & $0 \%$ & $0 \%$ & $0 \%$ & $100 \%$ & $0 \%$ \\
\hline & 2008 & $2,600,000$ & $0 \%$ & $0 \%$ & $0 \%$ & $100 \%$ & $0 \%$ \\
\hline & 2009 & $2,081,000$ & $0 \%$ & $0 \%$ & $0 \%$ & $94 \%$ & $6 \%$ \\
\hline & 2010 & $7,752,000$ & $0 \%$ & $0 \%$ & $0 \%$ & $100 \%$ & $0 \%$ \\
\hline \multirow{3}{*}{ ABC Brasil } & 2007 & $1,385,000$ & $0 \%$ & $0 \%$ & $0 \%$ & $100 \%$ & $0 \%$ \\
\hline & 2008 & $2,446,000$ & $0 \%$ & $0 \%$ & $0 \%$ & $100 \%$ & $0 \%$ \\
\hline & 2009 & $3,129,000$ & $0 \%$ & $0 \%$ & $0 \%$ & $100 \%$ & $0 \%$ \\
\hline
\end{tabular}




\begin{tabular}{|c|c|c|c|c|c|c|c|}
\hline \multirow{4}{*}{ Banco Pine } & 2007 & $3,021,000$ & $0 \%$ & $0 \%$ & $0 \%$ & $100 \%$ & $0 \%$ \\
\hline & 2008 & $3,369,000$ & $0 \%$ & $0 \%$ & $0 \%$ & $100 \%$ & $0 \%$ \\
\hline & 2009 & $2,090,000$ & $0 \%$ & $0 \%$ & $0 \%$ & $100 \%$ & $0 \%$ \\
\hline & 2010 & $3,292,000$ & $0 \%$ & $0 \%$ & $0 \%$ & $100 \%$ & $0 \%$ \\
\hline \multirow{4}{*}{ Paraná } & 2007 & 401,000 & $0 \%$ & $0 \%$ & $0 \%$ & $100 \%$ & $0 \%$ \\
\hline & 2008 & $56,086,008$ & $98 \%$ & $0 \%$ & $0 \%$ & $2 \%$ & $0 \%$ \\
\hline & 2009 & $53,727,009$ & $99 \%$ & $0 \%$ & $0 \%$ & $1 \%$ & $0 \%$ \\
\hline & 2010 & 414,000 & $1 \%$ & $0 \%$ & $0 \%$ & $0 \%$ & $99 \%$ \\
\hline \multirow{4}{*}{ Banestes } & 2007 & $7,569,000$ & $0 \%$ & $0 \%$ & $0 \%$ & $100 \%$ & $0 \%$ \\
\hline & 2008 & $6,754,000$ & $0 \%$ & $0 \%$ & $0 \%$ & $100 \%$ & $0 \%$ \\
\hline & 2009 & $5,237,000$ & $0 \%$ & $0 \%$ & $0 \%$ & $100 \%$ & $0 \%$ \\
\hline & 2010 & $4,940,000$ & $0 \%$ & $0 \%$ & $0 \%$ & $100 \%$ & $0 \%$ \\
\hline \multirow{2}{*}{ BRB } & 2009 & $23,045,000$ & $0 \%$ & $0 \%$ & $0 \%$ & $100 \%$ & $0 \%$ \\
\hline & 2010 & $20,905,000$ & $0 \%$ & $0 \%$ & $0 \%$ & $100 \%$ & $0 \%$ \\
\hline \multirow{3}{*}{$\begin{array}{l}\text { Mercantil do } \\
\text { Brasil }\end{array}$} & 2008 & $30,618,000$ & $0 \%$ & $0 \%$ & $0 \%$ & $100 \%$ & $0 \%$ \\
\hline & 2009 & $31,230,000$ & $0 \%$ & $0 \%$ & $0 \%$ & $100 \%$ & $0 \%$ \\
\hline & 2010 & $32,605,000$ & $0 \%$ & $0 \%$ & $0 \%$ & $100 \%$ & $0 \%$ \\
\hline
\end{tabular}

Source: Data collected for the study (2011).

The most frequently disclosed category throughout the study period was "infrastructure assets". The category was disclosed by all the banks in the sample (Table 6).

The present study offers some important findings in view of the importance of the intangible assets goodwill on merger and goodwill on acquisition of controlled companies by financial institutions. However, in Brooking's classification (1996), goodwill on merger and on acquisition is included in the definition of market assets, rather than a separate item of analysis.

As shown in Table 5, the sampled banks disclosed these categories of intangible assets in 2008 (three entries), 2009 (two entries) and 2010 (one entry), but only one of these was identified as goodwill on merger in 2008 .

Goodwill on acquisition was disclosed by Banco Bradesco S.A. regarding the acquisition (incorporation of shares) of Odontoprev. It is also important to mention that all firms reported that registered goodwill was subject to impairment testing at least once a year, whenever a decrease in the allocated asset's recoverable value was indicated, as specified by IAS 38 (2008) and CPC 04 (2008).

Interestingly, human-centered assets were highly representative in statements issued by ItauUnibanco, Santander, Banco do Brasil and Banrisul. This seems to depart from the results published by Santos et al. (2011) in a study on firms traded on BM\&FBovespa and included in the ranking of innovative firms of the Brazilian Index of Innovation (IBI). In their study, no human-centered assets were identified. According to Brooking (1996), human-centered assets are potential benefits derived from the expertise, creativity, knowledge and problemsolving skills of individuals, considered collectively and dynamically (Table 1).

Only two banks in our sample (Bradesco and ItauUnibanco) disclosed assets in the category "intellectual property assets". In Brooking's words (1996), intellectual property assets require legal protection in order to benefit organizations (e.g. knowhow, industrial secrets, copyrights, patents, design) (Table 1).

The category "other intangible assets" included assets identified as such by the disclosing organizations. Investments in this category were only representative in one bank (B14), and specifically in 2010. We believe the discrepancy may be due to difficulties in classifying intangible resources, rather than changes in actual asset composition.

4.2 Representativeness of Intangible Assets Disclosed in Accounting Statements in Relation to Total Assets and Non-current Assets throughout the Study Period

Based on information retrieved from balance sheets for the years 2007, 2008, 2009 and 2010 and, when necessary, explanatory notes, we evaluated the representativeness of intangible assets in relation to total assets (Figure 1) and non-current assets (Figure 2).

To facilitate visualization, we excluded banks that did not provide information on the representativeness of intangible assets in relation to total assets (B7, B8, B9, $\mathrm{B} 10, \mathrm{~B} 11, \mathrm{~B} 12$ and B13). For a list of codes assigned to the banks in the final sample, see Table 2. 
Figure 1. Representativeness of investments in intangible assets in relation to total assets.

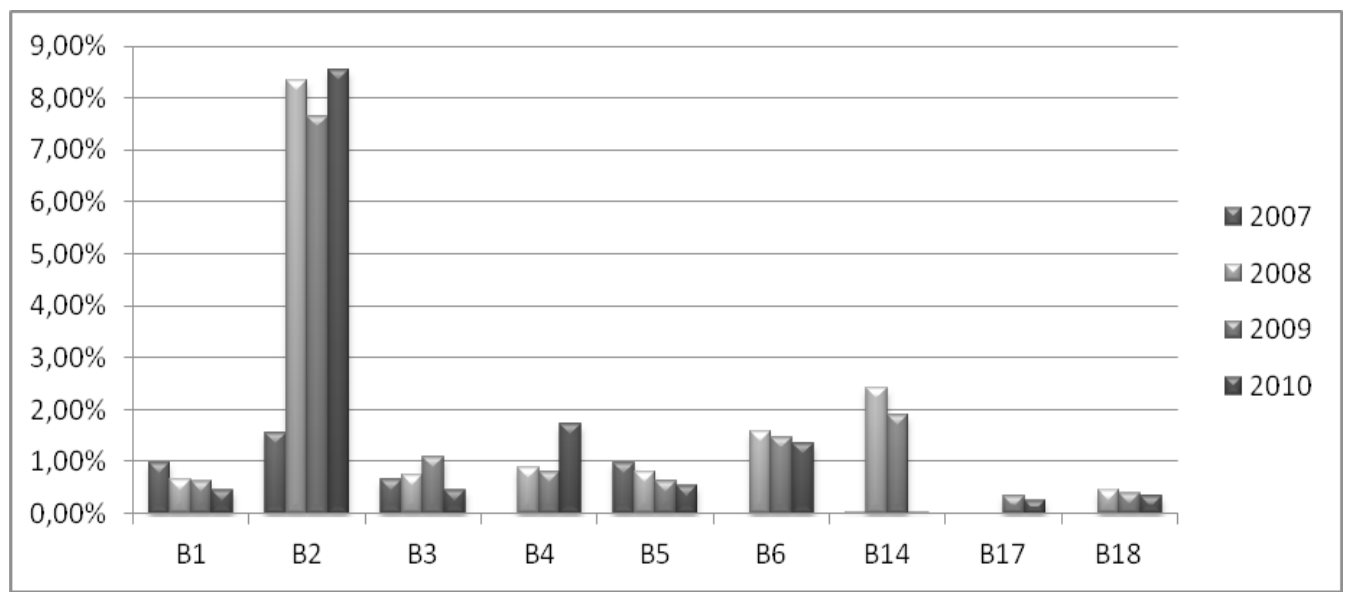

Source: Data collected for the study (2011).

The representativeness of intangible assets in relation to total assets was between $0 \%$ and $1.5 \%$ in 2007 (Figure 1). The figures for 2008 ranged between $0 \%$ and $2.5 \%$, with one notable exception (B2: 8.5\%). The following year, a reduction in the representativeness of intangible assets was observed in most banks. In 2010 the index behaved somewhat inconsistently: in some institutions the index shrank to $0 \%$, in others it reached peak values for the study period. In a similar analysis involving 45 public firms, Comunelo, Marcon and Thiesen (2010) found that in approximately $64 \%$ of the sampled organizations, intangible assets accounted for less than $1 \%$ of total assets. Thus, in some of the analyzed banks the representativeness of intangible assets in relation to total assets was above average, especially in the participants (B1, B3 and B4) of the survey conducted by IAM Consulting in partnership with Brand Finance (THE BRANDER, 2009).

Figure 2 illustrates the representativeness of intangible assets in relation to non-current assets as disclosed by the banks in our sample in 2007, 2008, 2009 and 2010. To facilitate visualization, we excluded banks that did not provide information on the representativeness of intangible assets in relation to non-current assets (B8, B9, B10, B11 and B12).

Figure 2. Representativeness of investments in intangible assets in relation to non-current assets

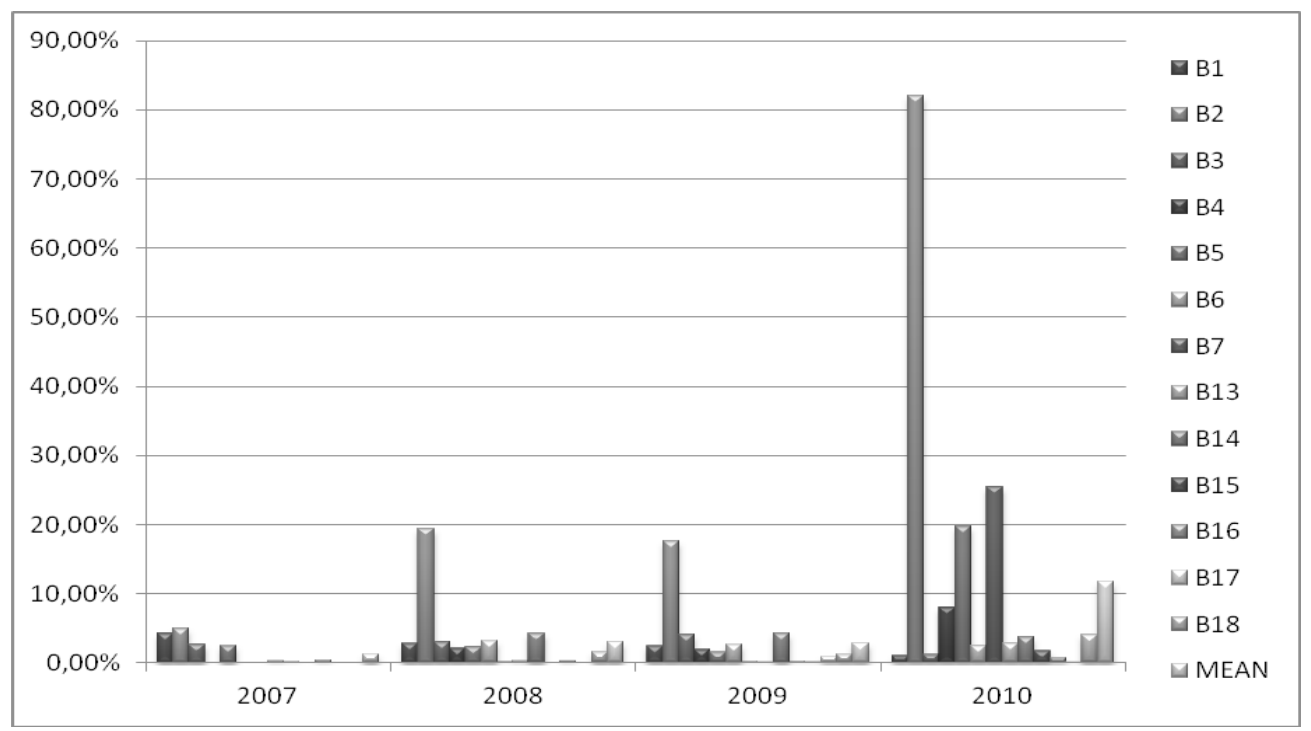

Source: Data collected for the study (2011).

It may be seen from Figure 2 that on the average the representativeness of intangible assets increased throughout the study period. This is supported by Backes, Ott and Wiethauper (2005) who observed the proportion of investments in intangible assets in Brazilian firms change from irrelevant to significant over relatively few years. In our sample, the index rose especially between $2007(1.15 \%)$ and 2008 (3.00\%) and between 2009
$(2.85 \%)$ and $2010(11.75 \%)$. Similar conclusions were reached by Marques (2009) in a study revealing that most firms included in the PSI-20 presented an increase in investments in intangible assets in 2007, indicating a growing interest in intangible resources among Portuguese firms.

Banco Santander (B2) differed greatly from the rest 
of the sample with regard to the representativeness of intangible assets in relation to both total and non-current assets, especially after 2008, due to more efficient asset recognition and quantification.

In general, the representativeness of intangible assets in relation to non-current assets increased, especially in 2009 and 2010, whereas the degree of intangibility (DI) was mostly lower in 2010 than in 2007. This will be discussed in the following sections.
4.3 Degree of Intangibility and Index of Investment in Intangible Assets, in General and by Period, Size and Stock Market Segment

With the purpose of determining whether company size was a conditioning factor of DI, we calculated the DI of the banks in the sample with the largest and smallest equity per year and the mean DI of each bank (Table 7). The banks were classified as "larger" (B1 to B9) or "smaller" (B10 to B18) based on the equity of 2009 as given in the ranking of "Exame Melhores e Maiores 2010".

Table 7. Degree of intangibility (DI) of the banks in the sample with largest and smallest equity throughout the study period (2007-2010).

\begin{tabular}{|c|c|c|c|c|c|c|}
\hline \multicolumn{7}{|c|}{ Banks with largest equity throughout the study period } \\
\hline \multirow{2}{*}{$\begin{array}{c}\text { Ranking of "Exame } \\
\text { Melhores e Maiores } \\
\text { 2010" }\end{array}$} & \multirow{2}{*}{ Bank } & \multicolumn{4}{|c|}{ Degree of intangibility } & \multirow{2}{*}{$\begin{array}{l}\text { Average DI for the period } \\
\text { 2007-2010 }\end{array}$} \\
\hline & & 2007 & 2008 & 2009 & 2010 & \\
\hline $1 \mathrm{st}$ & Itaú Unibanco - B1 & 3.66 & 2.22 & 3.05 & 2.35 & 2.82 \\
\hline 2nd & Santander (Brasil) - B2 & 3.36 & 0.97 & 1.43 & 1.18 & 1.73 \\
\hline 3 rd & Bradesco - B3 & 3.54 & 1.91 & 2.47 & 2.28 & 2.55 \\
\hline 4 th & Banco do Brasil - B4 & 3.10 & 1.26 & 2.11 & 1.65 & 2.03 \\
\hline 9th & Banrisul - B5 & 1.57 & 0.86 & 1.66 & 1.69 & 1.45 \\
\hline 15 th & Banco Amazônia - B6 & 1.66 & 0.63 & 1.03 & 0.83 & 1.04 \\
\hline 16 th & Bicbanco-B7 & 2.15 & 0.55 & 1.75 & 1.73 & 1.55 \\
\hline 18 th & Daycoval - B8 & 2.50 & 0.73 & 1.24 & 1.57 & 1.51 \\
\hline 19th & Banco Alfa - B9 & 1.01 & 0.61 & 0.72 & 0.58 & 0.73 \\
\hline \multicolumn{2}{|l|}{ Average DI } & 2.51 & 1.08 & 1.72 & 1.54 & 1.71 \\
\hline
\end{tabular}

Banks with smallest equity throughout the study period

\begin{tabular}{|c|c|c|c|c|c|c|}
\hline \multirow{2}{*}{$\begin{array}{l}\text { Ranking of "Exame } \\
\text { Melhores e Maiores } \\
\text { 2010" }\end{array}$} & \multirow{2}{*}{ Bank } & \multicolumn{4}{|c|}{ Degree of intangibility } & \multirow{2}{*}{$\begin{array}{c}\text { Average DI for the period } \\
2007-2010\end{array}$} \\
\hline & & 2007 & 2008 & 2009 & 2010 & \\
\hline 20 th & Panamericano - B10 & 1.89 & 0.51 & 1.94 & -2.49 & 0.46 \\
\hline $23 \mathrm{rd}$ & ABC Brasil - B11 & 1.48 & 0.60 & 1.29 & 1.40 & 1.19 \\
\hline 25 th & Cruzeiro do Sul - B12 & 1.86 & 1.09 & 2.60 & 1.91 & 1.87 \\
\hline 29 th & Banco Pine - B13 & 2.02 & 0.35 & 1.07 & 1.45 & 1.22 \\
\hline 30 th & Paraná Banco - B14 & 1.23 & 0.32 & 1.19 & 1.44 & 1.04 \\
\hline $32 \mathrm{nd}$ & Banco Sofisa - B15 & 2.43 & 0.64 & 0.96 & 0.90 & 1.23 \\
\hline 34 th & Banestes - B16 & 4.56 & 1.51 & 1.59 & 1.15 & 2.20 \\
\hline 38 th & BRB Banco - B17 & 0.00 & 0.00 & 1.35 & 1.36 & 0.68 \\
\hline 39 th & Mercantil do Brasil - B18 & 0.96 & 0.47 & 0.56 & 0.83 & 0.71 \\
\hline \multicolumn{2}{|l|}{ Average DI } & 1.83 & 0.61 & 1.39 & 0.88 & 1.18 \\
\hline
\end{tabular}

Source: Data collected for the study (2011).

The results presented in Table 7 show that banks with larger equity tended to present higher average DI values, suggesting a positive association between company size and DI.

The average DI decreased from 2007 to 2010 in both larger and smaller banks (from 2.51 to 1.54 , and from 1.83 to 0.88 , respectively), possibly because an increasing number of intangible assets are being recorded in the balance sheet thereby reducing the proportion between market value and book value. In fact, intangible assets constitute an important indicator of the discrepancy between the total value of shares and book value disclosed in accounting reports (KAYO; FAMÁ, 2004).

Figure 3 shows the mean, minimum and maximum DI of the banks in the sample with the largest and smallest equity. 
Figure 3. Mean, minimum and maximum degree of intangibility (DI) of the banks in the sample with the largest and smallest equity.

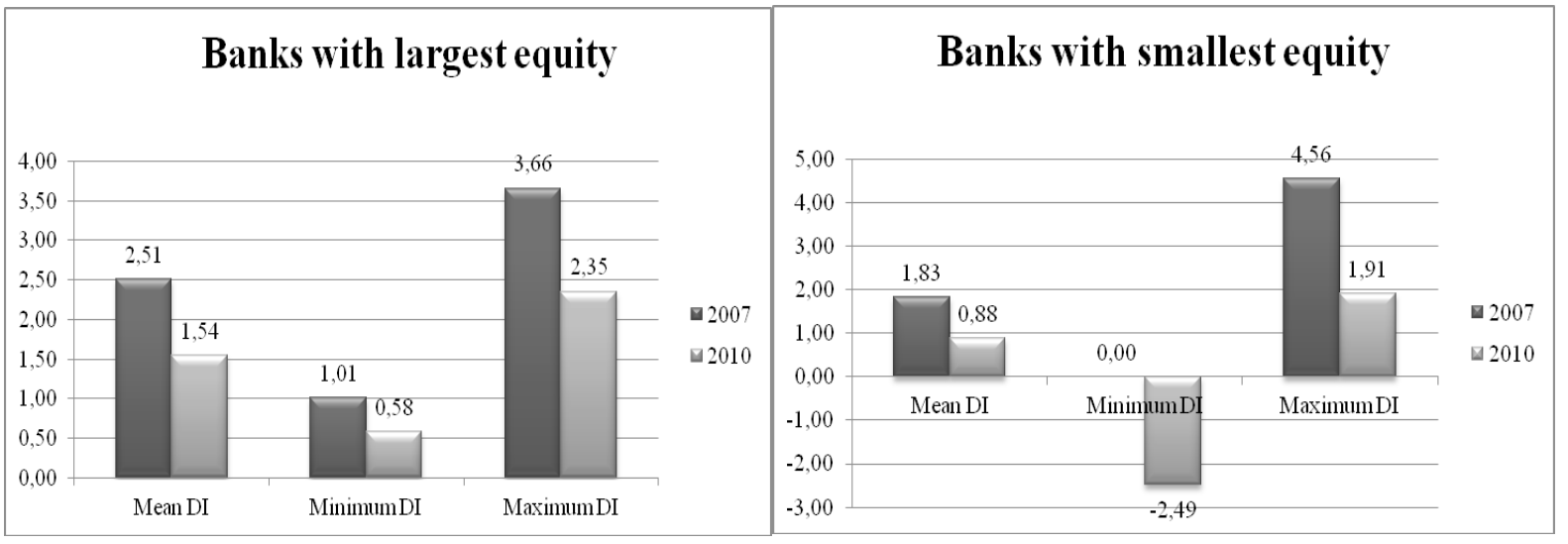

Source: Data collected for the study (2011).

In both groups of banks, the mean, minimum and maximum DI decreased throughout the study period (Figure 3). However, more importantly, larger banks presented higher average DI values for 2007 and 2010 than smaller banks, supporting the data presented in Table 7.

The observed reduction in DI between 2007 and 2010 may also be a repercussion of the global economic crisis in 2008 , the immediate effect of which was the plummeting of share prices in stock markets around the world. As foreign speculators rushed to sell their shares to cover losses in their home countries, the market value of many

Brazilian banks decreased significantly.

In order to determine whether listing segment was a conditioning factor of DI, we segregated the banks in the sample by BM\&FBovespa listing segment and calculated the mean DI of each segment for the period 2007-2010. To calculate the annual segment average we divided the sum of the DI of each year by the number of banks in the segment. The segment average for the entire the study period (2007-2010) was obtained by dividing the sum of the annual segment averages by four (Table 8 ).

Table 8. Mean degree of intangibility (DI) per year and BM\&FBovespa listing segment.

\begin{tabular}{c|c|c|c|c|c|c|c}
\hline \multirow{2}{*}{$\begin{array}{c}\text { BM\&FBOVESPA } \\
\text { segment }\end{array}$} & Number of & \multicolumn{4}{|c|}{ Mean DI per segment per year } & Mean DI per segment for the \\
banks & 9 & $\mathbf{2 0 0 7}$ & $\mathbf{2 0 0 8}$ & $\mathbf{2 0 0 9}$ & $\mathbf{2 0 1 0}$ & 1.61 \\
\hline L1 & 3 & 2.27 & 0.95 & 1.89 & 1.33 & 1.39 \\
\hline L2 & 1 & 2.42 & 0.74 & 1.23 & 1.16 & \\
\hline NM & 5 & 3.10 & 1.26 & 2.11 & 1.65 & \\
\hline TM & 1.64 & 0.47 & 1.05 & 0.95 & \\
\hline
\end{tabular}

Source: Data collected for the study (2011).

L1=Differentiated Level 1; L2= Differentiated Level 2; NM=New Market; TM=Traditional Market.

As shown, the mean DI was higher in banks in corporate governance-specific listing segments (New Market, Level 1, Level 2) than in banks traded on the traditional market (TM), indicating a possible positive association between listing segment and DI. Our results are supported by Ensslin et al. (2009) who reported the

mean DI of firms in the New Market segment (2.03) to be almost twice that of firms in the TM segment (1.07).

Figure 4 shows the behavior of the DI (the number of times market value is greater than book value, represented by equity) in our sample of banks in the period 2007 2010.

Figure 4. Behavior of the degree of intangibility (DI) of the banks in the sample in the period 2007-2010.

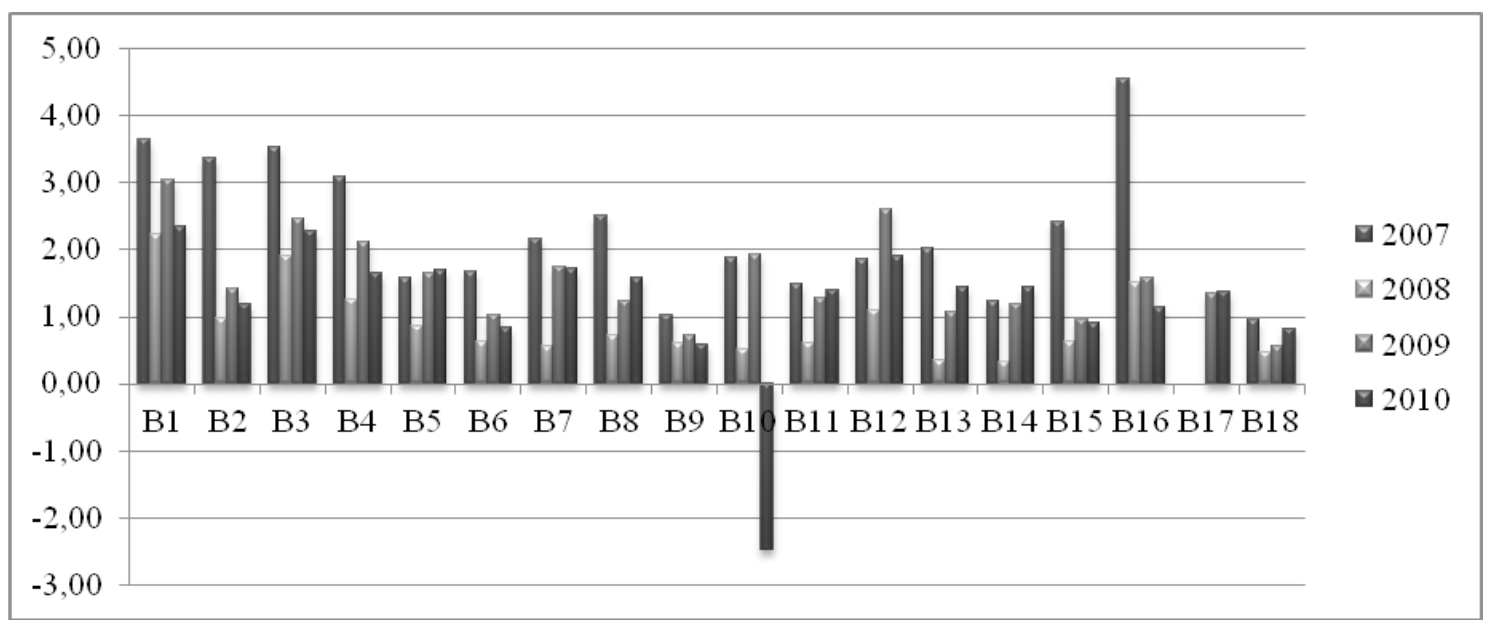

Source: Data collected for the study (2011). 
Throughout the study period, a decrease in DI was observed. This is particularly evident when comparing figures for 2007 (prior to changes in corporate legislation) and 2010. Based on these figures, it may be inferred that, overall, the difference between equity and market value decreased.

Figure 5. Behavior of the Index of Investments in Intangible Assets (IIIA) of the banks in the sample between 2007 and 2010

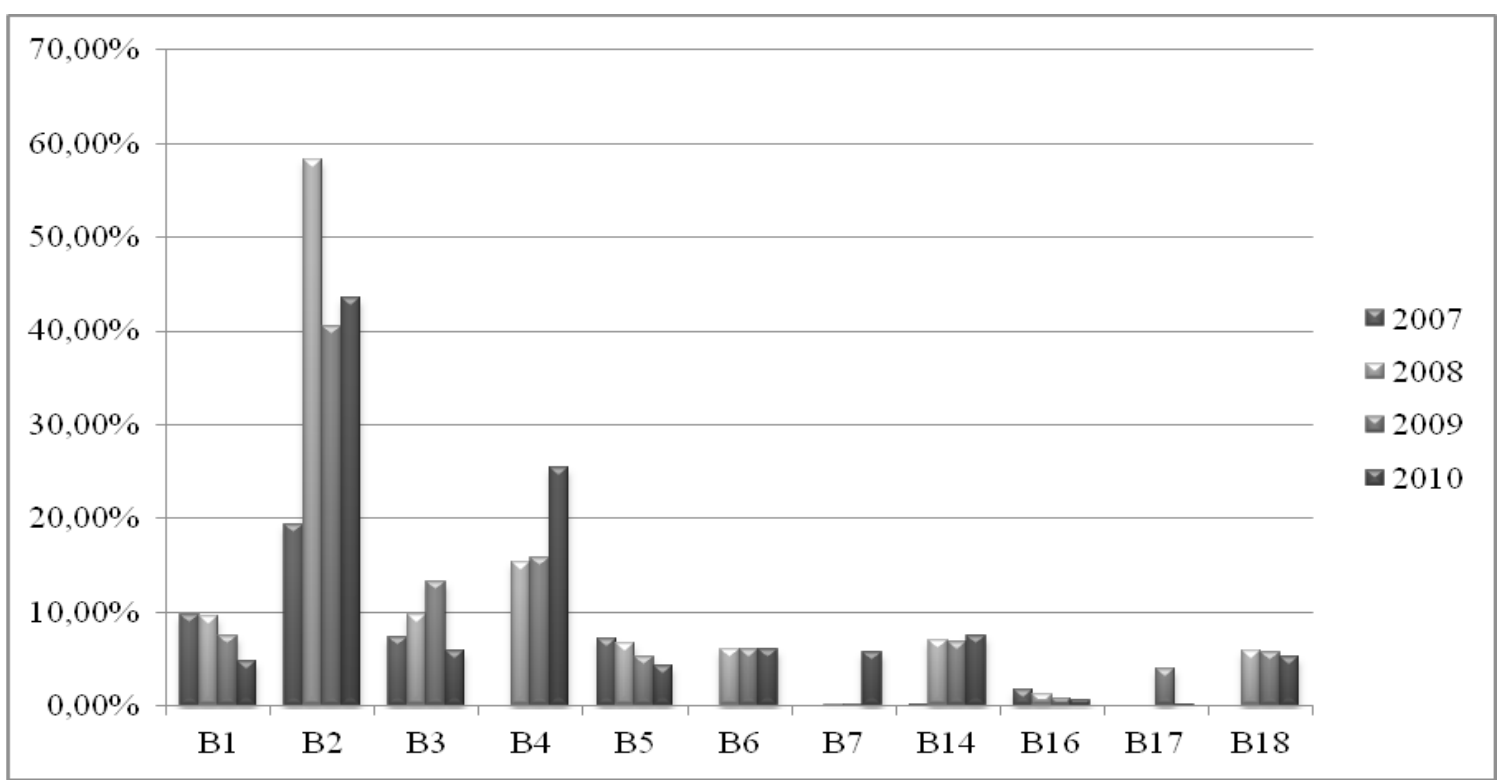

Source: Data collected for the study (2011)

Banks with an IIIA consistently below $0.5 \%$ (B8, B9, B10, B11, B12, B13 and B15) were not included in Figure 5. It may be inferred from Figure 5 that larger banks (greater equity, according to "Exame Maiores e Melhores 2010") tend to present higher IIIA values. In comparison, Ritta and Ensslin (2010) found IIIA values of $22.5 \%$ (2007) and $30.3 \%$ (2008) for firms included in the Bovespa Index (IBOVESPA).
The behavior of the IIIA, which indicates the level of corporate investments in intangible assets according to Ritta and Ensslin (2010), for the banks in our sample between 2007 and 2010 is illustrated in Figure 5. 
In 2010, IIIA had increased and DI had decreased in relation to figures for 2007, with two exceptions: in B5 the IIIA decreased and the DI increased, while in B16 both parameters decreased.

Table 9 also shows that, in some cases, IA-intensive and non-IA-intensive banks displayed similar DI values, suggesting the absence of an association between DI and investments in intangible assets.

According to Kayo, Kimura, Martin and Nakamura (2006), it is important to identify the determinants of intangibility and to understand how intangible assets aggregate value to firms. In fact, a number of researchers, including Chauvin and Hirschey (1993), Megna and Klock (1993), Villalonga (2004), Perez and Famá (2006a) and Ensslin et al. (2009), have investigated the influence of intangible resources on business performance.

The last table of our study illustrates the behavior of IA and market value of the country's largest banks in 2009 and 2010 (Table 10).

Table 10. Behavior of intangible assets and market value of the largest banks in Brazil in the period 2009-2010.

\begin{tabular}{|c|c|c|c|c|c|c|}
\hline \multirow{2}{*}{ Bank } & \multicolumn{3}{|c|}{ Intangible assets in BRL and percentage variation } & \multicolumn{3}{|c|}{ Market value in BRL and percentage variation } \\
\hline & 2009 & 2010 & Variation & 2009 & 2010 & Variation \\
\hline B1 & $3,748,220,000$ & $3,244,000,000$ & $-15.54 \%$ & $155,269,138,780$ & $160,720,117,500$ & $3.39 \%$ \\
\hline B2 & $26,155,836,000$ & $35,583,262,000$ & $26.49 \%$ & $92,046,540,380$ & $86,460,468,830$ & $-6.46 \%$ \\
\hline B3 & $5,516,024,000$ & $5,412,088,000$ & $-1.92 \%$ & $113,511,435,430$ & $109,759,327,250$ & $-3.42 \%$ \\
\hline B4 & $5,676,879,000$ & $13,842,278,000$ & $58.99 \%$ & $76,324,857,206,400$ & $89,884,112,940,740$ & $15.09 \%$ \\
\hline B5 & $180,129,000$ & $172,206,000$ & $-4.60 \%$ & $8,387,862$ & $7,568,163$ & $-10.83 \%$ \\
\hline B6 & $115,150,000$ & $114,864,000$ & $-0.25 \%$ & $1,956,633,360$ & $1,600,881,840$ & $-22.22 \%$ \\
\hline B7 & $2,298,000$ & $109,512,000$ & $97.90 \%$ & $3,115,070,950$ & $3,314,250,050$ & $6.01 \%$ \\
\hline B13 & $2,090,000$ & $3,292,000$ & $36.51 \%$ & $407,317,500$ & $578,850,000$ & $29.63 \%$ \\
\hline B16 & $5,237,000$ & $4,940,000$ & $-6.01 \%$ & $1,054,950,750$ & $924,076,800$ & $14.16 \%$ \\
\hline B17 & $23,045,000$ & $20,905,000$ & $-10.24 \%$ & $782,397,950$ & $1,114,020,000$ & $29.77 \%$ \\
\hline B18 & $31,230,000$ & $32,605,000$ & $4.22 \%$ & $124,748,757$ & $323,056,186$ & $61.38 \%$ \\
\hline Mean & $41,456,138,000$ & $\mathbf{5 8 , 5 3 9 , 9 5 2 , 0 0 0}$ & $1.86 \%$ & $76,693,133,828,120$ & $90,248,915,557,360$ & $0.88 \%$ \\
\hline
\end{tabular}

Source: Data collected for the study (2011).

Despite the overall increase in mean investments in intangible assets $(+1.86 \%)$ and market value $(+0.88 \%)$, no symmetry was found in the behavior of these parameters in view of the large and inconsistent oscillations observed (Table 10). Ensslin et al. (2009) obtained similar results in a study based on a sample of the top 60 firms in the BOVESPA index (IBOVESPA) over the period 20052007: annual oscillations were large and asymmetrical, and no correlation was found between variations in return on investment (ROI) and variations in DI.

\section{CONCLUSION}

The main purpose of the study was to analyze, in light of Institutional Theory, the behavior of the degree of intangibility of the largest banks listed on BM\&FBovespa in the period 2007-2010 with the purpose of evaluating the impacts of the mandatory introduction of new accounting practices regarding intangible assets in the accounting statements of these firms. To do so, we conducted a descriptive and qualitative study based on a review of documents and the literature.

Most of the banks in our sample disclosed intangible assets (IA) by category in their accounting reports, especially in explanatory notes. Following the passage in 2007 of Law 11.638 and the publication of CPC 04, an increasing number of banks have been disclosing intangibles, indicating a positive impact of the new accounting regulations on the informational quality of accounting reports, and supporting the claim of Institutional Theory that the institutional environment (in this case, accounting regulation policies) is a determining factor of organizational behavior.

As for the categorization of the disclosed intangibles, certain types of assets were increasingly recognized, or more fully disclosed in 2010, including the types "improvements to third-party property", "goodwill", "brands", "customer portfolio-related assets", "contractrelated assets", "IT developments", "expenditure on software acquisition", "Software-developed and under development", "software and systems", and "patents". 
The most representative types of intangible assets were "expenditure on acquisition and software development", "software and systems" and "acquisition of payrolls" with regard to frequency, and "goodwill" and "acquisition of payrolls" with regard to average amount of investment.

In terms of investment, the predominant classification of intangible assets in accordance with the system proposed by Brooking (1996) was "infrastructure assets", disclosed by all the banks in the sample. Human-centered assets were also a major component of the intangibles disclosed by four of the banks.

Overall, the representativeness of intangible assets oscillated very much from year to year in relation to total assets, but increased throughout the study period if compared to non-current assets.

Banks with greater equity tended to display a higher degree of intangibility, suggesting a possible positive association between this parameter and company size. The BM\&FBovespa listing segments with the highest and lowest DI were the "New Market" and the "Traditional Market", respectively. The mean DI of the sample decreased throughout the study period, suggesting a reduction in the discrepancy between market value and equity.

No symmetry was observed between variations in the index of investment in intangible assets (IIIA) and variations in the degree of intangibility (DI). In fact, in some cases, IA-intensive and non-IA-intensive banks displayed similar DI values. Likewise, no symmetry was observed between variations in the behavior of intangible assets and market value. In most cases, the behavior of these variables was highly inconsistent.

Despite its embryonic nature, the present study provides relevant and essential information on the composition of intangible assets as disclosed in accounting statements issued by the largest banks in Brazil (in terms of equity) and on the relation between IIIA and DI. Our findings indicate the importance of intangibility in financial institutions as an object of future research, especially considering the possibility of quantitative analyses. Future studies might also focus on the measurement and disclosure of the classification of intangible resources (e.g. human-centered assets), determinants of the degree of intangibility of banks and factors contributing to reduce the discrepancy between market value and book value, such as the adoption of fair value through changes in Brazilian accounting regulations.

\section{REFERENCES}

ALLEE, V. The value evolution: addressing larger implications of an intellectual capital and intangibles perspective. Journal of Intellectual Capital, v. 1, n. 1, p. 17-32, 2000.

ALMEIDA, M. S.; BERTUCCI, L. A.; FRACISCO, J. R. S.; AMARAL, H. F. Influência da crise financeira mundial na estrutura econômica das instituições financeiras bancárias brasileiras e seus reflexos no Índice de Basiléia: uma abordagem comparativa. Revista de Contabilidade e Organizações, v. 6, n. 16, p. 74-94, set./dez. 2012.

ANTUNES, M. T. P. A controladoria e o capital intelectual: um estudo empírico sobre sua gestão. Revista de Contabilidade \& Finanças - RC\&F, v. 17, n. 41 , p. $21-37,2006$.

ANTUNES, M. T. P.; MARTINS, E. Gerenciando o capital intelectual: uma abordagem empírica baseada na controladoria de grandes empresas brasileiras. Revista Eletrônica de Administração, v. 13, n. 1, p. 1-22, 2007.

ANTUNES, M. T. P.; LEITE, R. S. Divulgação de informações sobre ativos intangíveis e sua utilidade para analistas de investimentos. Revista Universo Contábil - RUC, v. 4, n. 4, p. 22-38, 2008.

ARRUDA, B. B. H.; CABRAL, T. G.; ARAÚJO, A. O. Evidenciação dos elementos do capital intelectual nos relatórios da administração de companhias brasileiras pertencentes ao nível 2 de governança corporativa. Revista Brasileira de Contabilidade, v. 39, n. 182, p. 33-45, 2010.

ASSAF NETO, A. Mercado financeiro. 11. ed. São Paulo: Atlas, 2012.

BACKES, R. G.; OTT, E.; WIETHAEUPER, D. Evidenciação do capital intelectual: análise de conteúdo dos relatórios de administração de companhias abertas brasileiras. In: Encontro Nacional da ANPAD - ENANPAD, 29, 2005, Brasília. Anais... Brasília, ANPAD, 2005.

BALL, R.; KOTHARI, S. P.; ROBIN, A. The effect of international institutional factors on properties of accounting earnings. Journal of Accounting and Economics, v. 29, p. 1-51, 2000.

BM\&FBovespa - Bolsa de Valores, Mercadorias e Futuros. Available in: http://www.bmfbovespa. com.br. Accessed 12 january 2011.

BOLLEN, L.; VERGAUWEN, P.; SCHNIEDERS, S. Linking intellectual capital and intellectual property to company performance. Management Decision, v. 43, n. 9, p. 1161-1185, 2005.

BRASIL. Lei n. 6.404, de 15 de dezembro de 1976. Dispõe sobre as sociedades por ações. Available in: $\quad$ http://www.planalto.gov.br/ccivil.../Leis/ L6404consol.htm. Accessed 26 January 2011.

BRASIL. Lei n. 11.638, de 28 de dezembro de 2007. Altera e revoga dispositivos da Lei n. 6.404/ 1976 e da Lei n. 6.385 1976, e estende às sociedades de grande porte disposições relativas à elaboração e divulgação de demonstrações financeiras. Available 
in: http://www.planalto.gov.br/ccivil 03/ ato20072010/2007/Lei/L11638.htm. Accessed 6 december 2011.

BRASIL. Lei n. 11.941, de 27 de maio de 2009. Altera a legislação tributária federal relativa ao parcelamento ordinário de débitos tributários; institui regime tributário de transição e dá outras providências. Available in: http://www.planalto.gov.br/.../2009/ lei/111941.htm. Accessed 6 december 2011.

BROOKING, A. Intellectual capital: core asset for the third millennium enterprise. Boston: Thomson Publishing Inc, 1996.

BUKH, P. N.; LARSEN, H. T.; MOUTSSEN, J. Constructing intellectual capital for communities. Oxford: Elservier ButterworthHeinemann, 2005.

CALIL, C. F. E. Posicionamento social e desempenho financeiro: uma análise na indústria bancária brasileira a partir de uma tipologia proposta. 100 p. 2006. Unpublished $\mathrm{PhD}$ Dissertation, Master in Administration, Programa de Pós-graduação em Administração de Empresas da Pontifícia Universidade Católica do Rio de Janeiro, Rio de Janeiro, RJ, 2006.

CARPENTER, V. L.; FEROZ, E. H. Institutional theory and accounting rule choice: an analysis of four U.S. state governments' decisions to adopt generally accepted accounting principles. Accounting, Organizations and Society, v. 26, n. 7-8, p. 565596, 2001.

CARVALHO, F. M.; ENSSLIN, S. R. A evidenciação voluntária do capital intelectual: um estudo revisionista do contexto internacional. In: Congresso USP de Controladoria e Contabilidade, 7, 2006, São Paulo. Anais... São Paulo, FEA-USP, 2006.

CHAUVIN, K. W.; HIRSCHEY, M. Advertising, R\&D expenditures and the market value of the firm. Financial Management, v. 22, n. 4, p. 128-140, 1993.

COLAUTO, R. D.; NASCIMENTO, P. S.; AVELINO, B. C.; BISPO, O. N. A. Evidenciação de ativos intangíveis não adquiridos nos relatórios da administração das companhias listadas nos níveis de governança corporativa da Bovespa. Contabilidade Vista \& Revista, v. 20, n. 1, p. 142-169, 2009.

Comissão de Valores Mobiliários. Deliberação CVM n. 553, de 12 de novembro de 2008. 2008. Available in: http://www.cvm.gov.br/asp/cvmwww/atos/ Atos Redir.asp?Tipo $=$ D\&File $=\% 5$ Cdeli $\% 5 \mathrm{Cde}$ li553.doc. Accessed 6 March 2011.

Comissão de Valores Mobiliários. Deliberação CVM n. 644, de 2 de dezembro de 2010. 2010. http://www. cvm.gov.br/asp/cvmwww/atos/Atos_Redir.asp?Tip

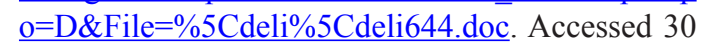
March 2011.
Comitê de Pronunciamentos Contábeis. 2008. Pronunciamento Técnico CPC 04 - Ativo intangível. Available in: http://www.cpc.org.br/ mostraOrientacao.php?id=27. Accessed 6 June 2011.

Comitê de Pronunciamentos Contábeis. 2010. Pronunciamento Técnico CPC 04 (R1) - Ativo intangível. Available in: http://www.cpc.org.br/pdf/ CPC04_R1.pdf. Accessed 6 June 2011.

COMUNELO, A. L.; MARCON, L. F.; THIESEN, A. P. Ativo intangível: sua representação nas empresas de capital aberto. In: Convenção dos Contabilistas do Paraná, 15, 2010, Curitiba. Anais... Curitiba, CRCPR, 2010.

CRISÓSTOMO, V. Ativos intangíveis: estudo comparativo dos critérios de reconhecimento, mensuração e evidenciação adotados no Brasil e em outros países. Contabilidade, Gestão e Governança, v. 12, n. 1, p. 50-68, 2009.

CRUBELLATE, J. M. Três contribuições conceituais neofuncionalistas à teoria institucional em organizações. Revista de Administração Contemporânea - RAC, v. 11, n. 1, p. 199-222, 2007.

DiMAGGIO, P. J.; POWELL, W. W. The iron cage revisited: institutional isomorphism and collective rationality in organizational fields. American Sociological Review, v. 48, n. 2, p. 147-160, 1983.

EDVINSSON, L.; MALONE, M. S. Capital intelectual: descobrindo o valor real de sua empresa pela identificação de seus valores internos. São Paulo: Makron Books, 1998.

ENSSLIN, S. R.; COUTINHO, I. G.; REINA, D.; ROVER, S.; RITA, C. Grau de intangibilidade e retorno sobre investimentos: um estudo entre as 60 maiores empresas do índice Bovespa. Revista Ciências Sociais em Perspectiva, v. 8, n. 14, p. 101-118, 2009.

Federação Brasileira de Bancos. 2011. Dados do setor: o setor bancários em números. Available in: http:// www.febraban.org.br/. Accessed 10 August 2011.

GUTHRIE, J.; PETTY, R. Intellectual capital literature review: measurement, reporting and management. Journal of Intellectual Capital, v. 1, n. 2, p. 155176, 2000.

HENDRIKSEN, E. S.; VAN BREDA, M. Teoria da contabilidade. 6. ed. São Paulo: Atlas, 2007.

HOPWOOD, A. G. Understanding financial accounting practice. Accounting, Organizations and Society, v. 25, n. 8 , p. $763-766,2000$.

International Accounting Standards Committee. 2008. International Accounting Standard (IAS) 38 - Intangible assets, de 03/07/2008. Available in: http://www.worldgaapinfo.com/pdf/IAS/IAS38. pdf. Accessed 3 April 2011. 
International Financial Reporting Standards. 2010. International Accounting Standard (IAS) 3 (R): business combinations, April, 2010. Available in: http://www.iasplus.com/en/standards/standard43. Accessed 8 Nov. 2013.

IRVINE, H. J. The global institutionalization of financial reporting: the case of the United Arab Emirates. Accounting Forum, v. 32, p. 125-142, 2008.

IUDÍCIBUS, S. Teoria da contabilidade. 7. ed. São Paulo: Atlas, 2004.

IUDÍCIBUS, S.; MARTINS, E.; GELBCKE, E. R.; SANTOS, A. Manual de contabilidade societária: aplicável a todas as sociedades de acordo com as normas internacionais e do CPC. São Paulo: Atlas, 2010 .

KAUFMANN, L.; SCHNEIDER, Y. Intangibles: a synthesis of current research. Journal of Intellectual Capital, v. 5, n. 3, p. 366-388, 2004.

KAYO, E. K. A estrutura de capital e o risco das empresas tangível e intangível intensivas: uma contribuição ao estudo da valoração de empresas. 110 p. 2002. Unpublished $\mathrm{PhD}$ Thesis in Administration, Faculdade de Economia, Administração e Contabilidade da Universidade de São Paulo, São Paulo, SP, 2002.

KAYO, E. K.; FAMÁ, R. A estrutura de capital e o risco das empresas tangível-intensivas e intangívelintensivas. Revista de Administração - USP, v. 39, n. 2, p. 164-176, 2004.

1. KAYO, E. K.; KIMURA, H.; MARTIN, D. M. L.; NAKAMURA, W. T. Ativos intangíveis, ciclo de vida e criação de valor. REVISTA DE ADMINISTRAÇÃO CONTEMPORÂNEA RAC, V. 10, N. 3, P. 73-90, 2006.

KOHLER, E. L. A dictionary for accountants. New York: Prentice-Hall, 1957.

KOT, E. M. How to conduct the audit of intellectual capital in Polish tourism business? Journal of Knowledge Management, v. 7, n. 4, p. 459-468, 2009

LAUX, C.; LEUZ, C. The crisis of fair-value accounting: market sense of the recent debate. Accounting, Organizations and Society, v. 34 , n. 6-7, p. 826834, Nov. 2009

LEV, B. Intangibles: management, measurement and reporting. Washington: Brookings Institution Press, 2001.

LIMA, V. S.; LIMA, G. A. S. F.; LIMA, I. S.; CARVALHO, L. N. G. C. Determinantes da convergência aos padrões internacionais de contabilidade no Brasil. In: Congresso da Associação Nacional de Programas de Pós-Graduação em Ciências Contábeis - Congresso ANPCONT, 4, 2010, Natal. Anais... Natal, ANPCONT, 2010.
LUCENA, W. G. L.; FERNANDES, M. S. A.; FRANÇA, J. A.; CAPELLETTO, L. R. Estudo do nível de evidenciação do impairment pelos bancos brasileiros: uma aplicação da análise do conteúdo com base nas notas explicativas. Revista Contabilidade e Controladoria - RC\&C, v. 1, n. 1, p. 45-60, 2009.

MARQUES, M. C. C. Os activos intangíveis nas contas das empresas do PSI 20: uma evidência empírica. Pecvnia, v. 8, p. 183-201, 2009.

MARR, B.; SCHIUMA, G.; NEELY, A. The dynamics of value creation: mapping your intellectual performance drivers. Journal of Intellectual Capital, v. 5, n. 2, p. 312-325, 2004.

MARTINS, J.; BICUDO, M. A. V. A pesquisa qualitativa em psicologia: fundamentos e recursos básicos. São Paulo: EDUC / Moraes, 1989.

MEGNA, P.; KLOCK, M. The impact of intangible capital on Tobin's q in the semiconductor industry. American Economic Review, v. 83, n. 2, p. 265269,1993

MEIRELLES, F. S. Estudo dos gastos e investimentos em TI: avaliação, evolução e tendências nos principais bancos nacionais. 2. ed. São Paulo: GVpesquisa; FGV-EAESP, 2010.

NOBES, C. The survival of international differences under IFRS: towards a research agenda. Accounting and Business Research, v. 36, n. 3, p. 233-245, 2006.

PABLOS, P. O. Measuring and reporting structural capital: lessons from European learning firms. Journal of Intellectual Capital, v. 5, n. 4, p. 629647,2004

PATROCÍNIO, M. R: KAYO, E. K.; KIMURA, H. Aquisição de empresas, intangibilidade e criação de valor: um estudo de evento. Revista de Administração - USP, v. 42, n. 2, p. 205-215, 2007.

PEREZ, M. M.; FAMÁ, R. Ativos intangíveis e o desempenho empresarial. Revista Contabilidade \& Finanças-RC\&F, v. 40, p. 7-24, 2006a.

PEREZ, M. M.; FAMÁ, R. Características estratégicas dos ativos intangíveis e o desempenho econômico da empresa. Revista Eletrônica de Gestão de Negócios, v. 2, n. 2, p. 69-96, 2006 b.

POTTER, B. N. Accounting as a social and institutional practice: perspectives to enrich our understanding of accounting change. ABACUS, v. 41, n. 3, p. 265$289,2005$.

QUINTEIRO, C. E. Evidenciação do capital intelectual nos bancos abertos no Brasil e na Espanha. 151 p. 2009. Unpublished PhD Dissertation, Master in Accounting, Programa de Mestrado em Ciências Contábeis da Faculdade de Economia, Administração e Contabilidade da Universidade de São Paulo, São Paulo, SP, 2009 
REINA, D.; VICENTE, E. F. R.; ENSSLIN, S. R. Capital intelectual: uma análise comparativa da evidenciação voluntária em empresas de governança corporativa no ano de 2006. In: Congresso Brasileiro de Contabilidade, 18, 2008, Gramado. Anais... Gramado, ABC, 2008.

Revista Exame Melhores e Maiores. 2010. Edição 971-E. São Paulo: Abril, 2010.

REZENDE, Y. Informação para negócios: os novos agentes do conhecimento e a gestão do capital intelectual. Caderno de Pesquisas em Administração, v. 8, n. 1, p. 11-21, 2001.

RICHARDSON, R. J. Pesquisa social: métodos e técnicas. 3. ed. São Paulo: Atlas, 1999.

RITTA, C. O.; ENSSLIN, S. R. Investigação sobre a relação entre ativos intangíveis e variáveis financeiras: um estudo nas empresas brasileiras pertencentes ao índice IBovespa nos anos de 2007 e 2008. In: Congresso USP de Controladoria e Contabilidade, 10, 2010, São Paulo. Anais... São Paulo, FEA-USP, 2010.

ROOS, J.; EDVINSSON, L.; ROOS, G. Intellectual capital: navigating the new business landscape. New York: New York University Press, 1998.

SANTOS, J. G. C., SILVA, L. S. \& GALLON, A. V. 2011. Os ativos intangíveis de empresas inovadoras. In: Simpósio de Administração da Produção - SIMPOI, 14, 2011, São Paulo. Anais... São Paulo, FGVEAESP, 2011.

SANTOS, J. L.; SCHMIDT, P. Análise e evidenciação contábil da propriedade intelectual. Revista ConTexto, v. 2, n. 3, p. 1-11, 2002.

SANTOS, J. L.; SCHMIDT, P. Avaliação de ativos intangíveis: goodwill, capital intelectual, marcas e patentes, propriedade intelectual, pesquisa e desenvolvimento. 2. ed. São Paulo: Atlas, 2009.

SILVA, A. D.; ALPERSTEDT, G. D. Mudança organizacional estratégica em um banco público: uma análise a partir da perda da conta movimento. Revista de Administração Pública, v. 47, n. 4, p. 827 848, jul./ago. 2013.

STEWART, T. A. Capital intelectual: a nova vantagem competitiva das empresas. Rio de Janeiro: Campus, 1998.

SVEIBY, K. E. Methods for measuring intangibles assets. 1997. Available in: http://www.sveiby.com. Accessed 26 January 2011.

The Brander. 3. ed. 2009. Available in: http://www. thebrander.com/. Accessed 10 January 2011.

VILLALONGA, B. Intangible resources, Tobin's q and sustainability of performance differences. Journal of Economic Behavior \& Organization, v. 54, n. 2, p. 205-230, 2004.

ZILBER, S. N.; PAJARES, F. M. R. Análise da vantagem competitiva de bancos em países emergentes e em países desenvolvidos utilizando o modelo de visão baseada em recursos: estudo comparativo Brasil $\mathrm{x}$ Estados Unidos. Economia Global e Gestão, v. 14, n. 2, p. 95-117, 2009. 